腎細胞癌患者における動脈血および腫瘍側腎静脈血間での

$$
\text { リンパ球サブセットの比較 }
$$

\begin{tabular}{|c|c|c|c|}
\hline 白岩 & 浩志1) & 西島由貴子 & 赤座 英之 \\
\hline 内田 & 克紀 & 河合 & 佐々木 明 \\
\hline 报咅 & 一紀 & 宮永 直 & 小磯 \\
\hline
\end{tabular}

\title{
PHENOTYPIC DIFFERENCE OF LYMPHOCYTES CIRCULATING IN TUMOROUS RENAL ARTERY AND RENAL VEIN IN PATIENTS WITH RENAL CELL CARCINOMA
}

\begin{abstract}
Hiroshi Shiraiwa, Yukiko Nishijima, Hideyuki Akaza, Katsunori Uchida, Koji Kawai, Akira Sasaki, Kazunori Hattori, Naoto Miyanaga and Kenkichi Koiso

Department of Urology, Institute of Clinical Medicine, University of Tsukuba
\end{abstract}

(Chief: Prof. K. Koiso)

Phenotypic difference of lymphocytes circulating in tumorous renal artery and renal vein in patients with renal cell carcinoma was studied.

Fifteen patients with no prior treatment were studied, from whom blood samples were taken at the time of radical nephrectomy. Mononucler cells separated from tumorous renal arterial and venous blood were analyzed for cell surface markers. CD3, CD4, CD8, CD11b, CD16, CD25, CD57, Leu8 HLA-DR were compared. CD25 positive cells were significantly increased in venous blood than in arterial blood in the kidneys with tumor. No significant difference was found regarding the other surface markers.

Key words: renal cell carcinoma, phenotypic analysis of lymphocyte

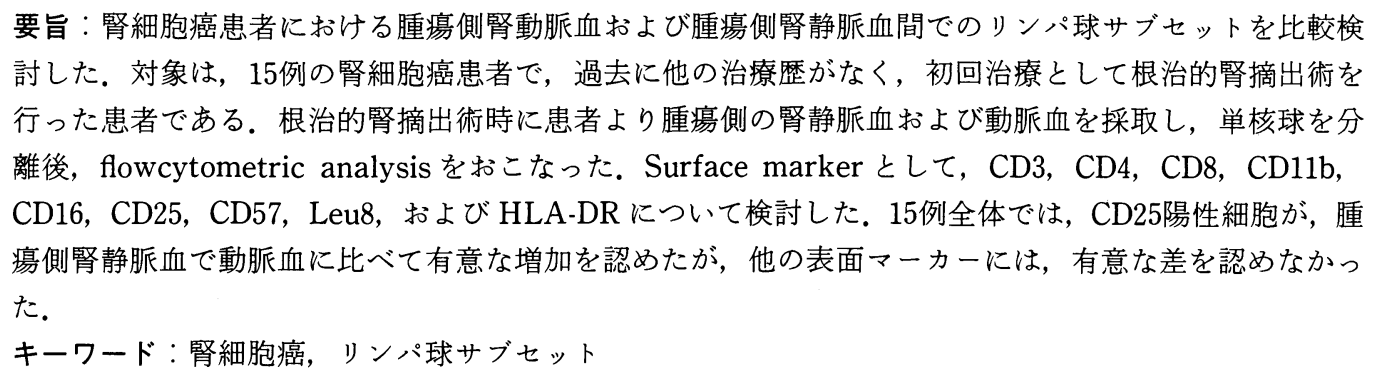

\section{緒 言}

腎癌患者での腫瘍側腎動脈血および腫瘍側腎静脈血 中のリンパ球に関する比較では，1982年に Akaza ら が腫瘍側腎静脈血で IgG Fc レセプター陽性 T 細胞の 増加と, ADCC 活性の増加を報告している ${ }^{1)}$. 測定技術

\footnotetext{
${ }^{1}$ 現 茨城県立中央病院・茨城県地域がんセンター泌尿
} 器科
の進歩により，詳細なリンパ球サブセットの検討が可 能となったため, 今回, 我々は, 腎細胞癌患者のホス 卜と腫瘍の関係を探る目的で, 腎細胞癌患者における 動脈血および腫瘍側腎静脈血間でのリンパ球サブセッ トを比較検討したので報告する。

\section{対象ならびに方法}

対象は，1990年 6 月から1991年12月に筑波大学附属 病院泌尿器科に入院した腎細胞癌患者で, 過去に他の 
治療歴がなく, 初回治療として根治的腎摘出術を行っ た患者で, 病理組織学的に腎細胞癌と診断された患者 である。症例は，男性 7 例，女性 8 例の計15例で，平 均年齢は61.5歳であった. Performance Status は，0 または 1 が14例， 3 が 1 例であった。 また，手術時に 遠隔転移の認められた症例は 5 例, 認められなかった 症例は10例であった。

試験の方法は, 経腹的な根治的腎摘出術時の腎動静 脈を結紮する直前に腫瘍側腎動脈血および腫瘍側腎静 脈血を術野より採取し, 単核球を分離後, flowcytometric analysisを抢こなった. 使用したモノク口 ナール抗体は, Leu4 (CD3), Leu3a (CD4), Leu2a (CD8), Leu15 (CD11b), Leu11c (CD16), Leu7 (CD57), IL-2R (CD25), Leu-DR (HLA-DR) および Leu8である。

Surface marker として, CD3, CD4, CD8, CD11 b, CD16, CD25, CD57, Leu8, および HLA-DR につ いて検討した。 また, two color analysisは, $\mathrm{CD} 4 \times$ Leu8, CD $4 \times$ HLA-DR, CD8 $\times$ CD11b, CD $8 \times$ HLA$\mathrm{DR}, \mathrm{CD} 16 \times \mathrm{CD} 57, \mathrm{CD} 3 \times \mathrm{CD} 25$ の組み合わせについて 検討した. $\mathrm{CD} 3 \times \mathrm{CD} 25$ にいては 5 例で, 残りの組み 合わせについては15例全例で検討した。これらの測定 は, 大塚アッセイ研究所に依頼して行った.

\section{結果}

初めに，15例全体での結果を示す。

One color assay では，CD25陽性細胞が，腫瘍側腎 静脈血の絶対数で，327.4 122 であり，腎動脈血で $289.5 \pm 121$ と腎静脈血が腎動脈血に比べて有意（ $\mathrm{p}<$ 0.05)な増加を認めた。しかし, CD3, CD4, CD8, CD16,

図 1 全症例についての動脈血および腫瘍側腎静脈血 間でのリンパ球サブセットの比較

動脈血（糍），腫瘍側腎静脈血（口）

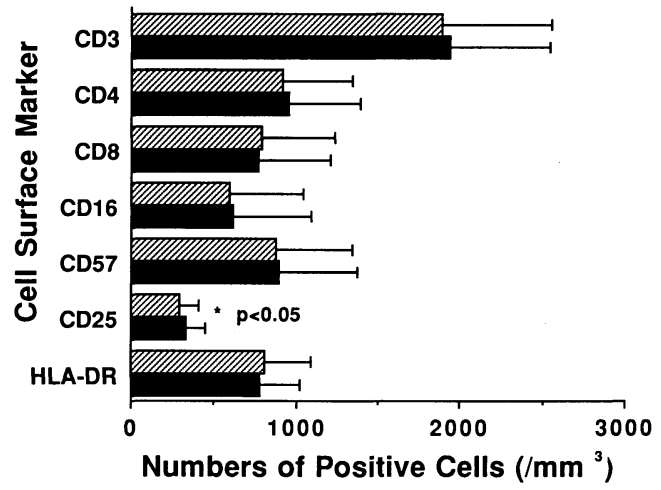

図 2 全症例についての動脈血および腫瘍側腎静脈血 間での Two color assayによるリンパ球サブセッ トの比較

動脈血（新），腫瘍側腎静脈血
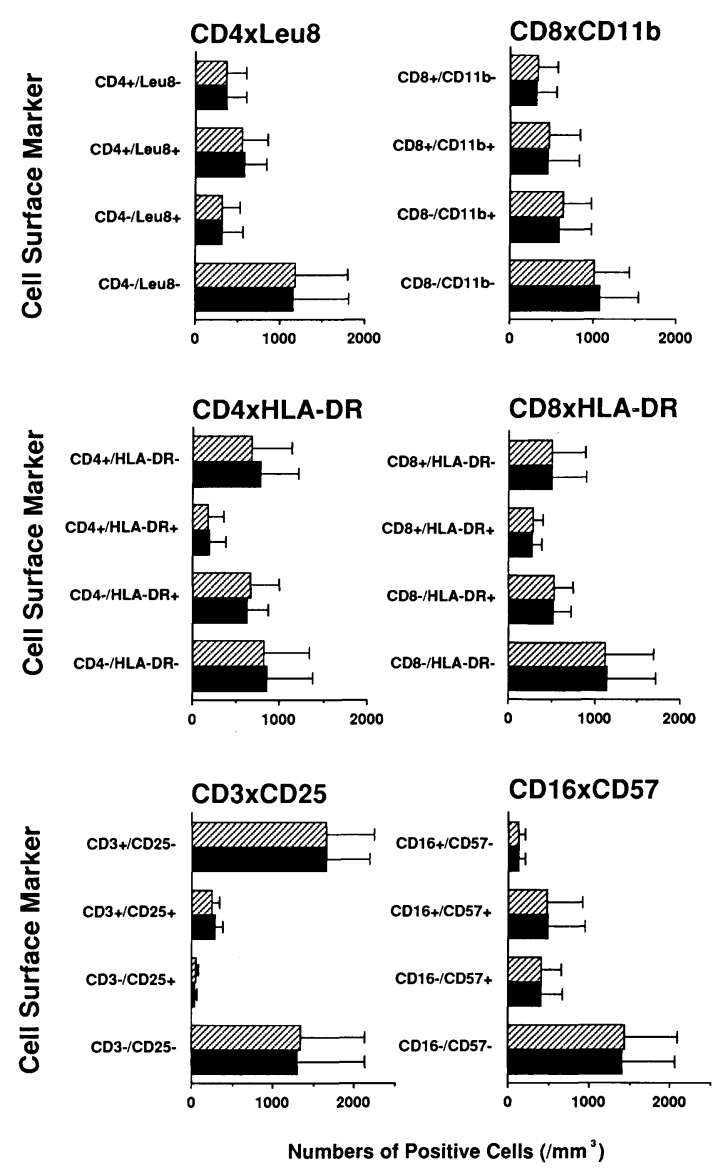

図 3 遠隔転移の有無で分けた場合の動脈血および腫 瘍側腎静脈血間でのリンパ球サブセットの比較 動脈血（约），腫瘍側腎静脈血

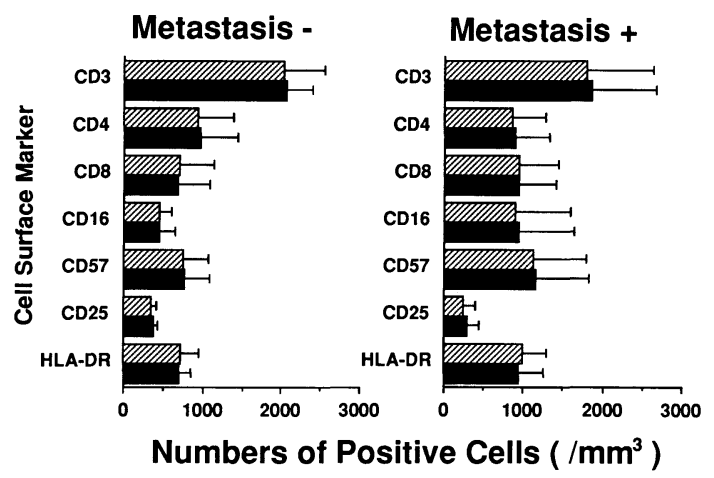


CD57, HLA-DR 陽性細胞は, 動静脈間に有意な差を認 めなかった（図 1).

Two color assay では, CD3と CD25の組み合わせ で, CD3陽性かつ CD25陽性の細胞が腫瘍側腎静脈血 で動脈血に比べて増加する傾向を認めたが, 統計学的 に有意差は認めなかった。また, CD4 と Leu8, CD8 CD11b，CD4 と HLA-DR，CD8と HLA-DR，CD16 と CD57の組み合わせでは, 動静脈間に有意な差は認めな かった（図 2).

次に症例を遠隔転移の有無で分けたときの, 腫瘍側 腎動静脈間のリンパ球サブセットを比較検討した。 CD25陽性細胞については, 遠隔転移のある群で腫瘍側 腎静脈血中で動脈血中に比べて増加する傾向を認めた が，測定した症例数が少なく，統計学的な有意差は認

図 4 腎細胞癌患者動脈血リンパ球サブセットの遠隔 転移の有無による変化

遠隔転移有り（四），遠隔転移無し（目）

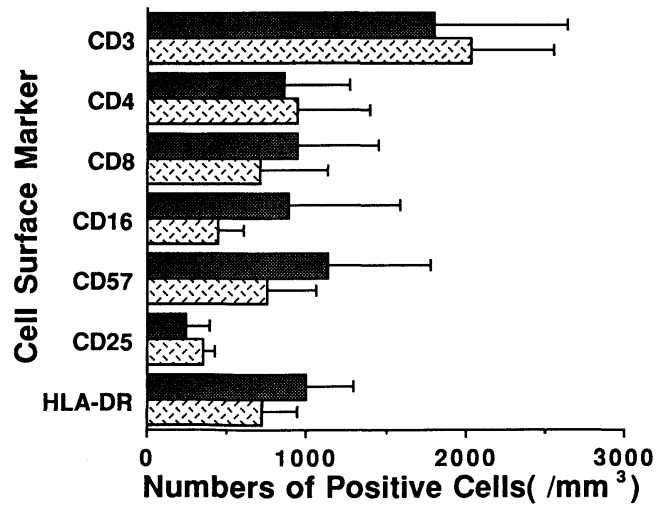

図 5 Two Color Assay による腎細胞癌患者動脈血 リンパ球サブセットの遠隔転移の有無による変化 遠隔転移有り (图)，遠隔転移無し（因）

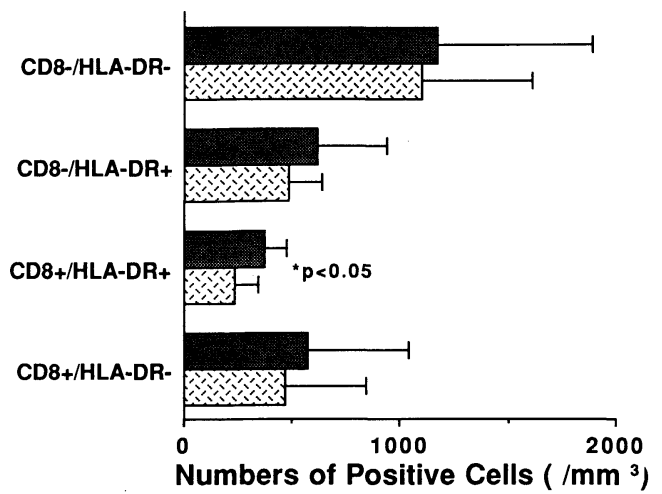

めなかった. CD3, CD4, CD8, CD16, CD57, HLA-DR では，遠隔転移の有無で分けて検討しても動静脈間に 有意な差を認めなかった（図 3 ）。をた，two color assayでも，いずれの組み合わせでも有意な差は認め なかった。

次に，同じ症例を用い，腎細胞癌患者の動脈血リン パ球サブセットの遠隔転移の有無による変化を検討し た。遠隔転移のある症例で, CD8, CD16, CD57, HLADR 陽性細胞が増加し，CD3，CD4，CD25陽性細胞が 減少する傾向を示したが，統計学的な有意差は認めな かった（図 4 )。Two color assay では，CD8陽性かつ HLA-DR 陽性細胞が遠隔転移のある症例で有意（ $\mathrm{p}<$ 0.05）に増加したが，他の組み合わせでは有意差は認 めなかった（図 5 ).

\section{考 察}

腎癌患者での腫瘍側腎動脈血および腫瘍側腎静脈血 中のリンパ球に関する比較では，1982年にAkazaら が腫瘍側腎静脈血で IgG Fcレセプター陽性 T 細胞の 増加と, $\mathrm{ADCC}$ 活性の増加を報告している1). しかし, 詳細なリンパ球サブセットを腫瘍側腎動静脈血間で比 較する研究は，現在までおこなわれていなかった。

本研究の結果, 腫瘍側腎静脈血では, 腎動脈血に比 べて CD25陽性細胞数が約13\%増加することが示され た。しかし，他の検討したリンパ球サブセットに有意 な変化は認められなかった。

現在， $\mathrm{T}$ 細胞レセプターを介した刺激と同等の刺激 と考它られている抗 CD3抗体による刺激およびイン ターロイキン 2 の刺激で CD25陽性細胞が増加するこ とが知られている2). 今回の我々の結果は, 末梢血単核 球が腫瘍側腎を通過する際に, 腫瘍局所において癌抗 原刺激およびインターロイキン 2 による刺激で CD25 陽性細胞が増加したと推測することも可能である。

一方, Akaza らがおこなった, IgG, Fcレセプター 陽性 $\mathrm{T}$ 細胞は, thymoma, hypogammmaglobulinemia, ataxiatelangiectasiaなどの患者で増 加し ${ }^{3)}$, 進行性膀脱癌患者でも増加したとの報告が認 められる4).

現在, IgGに対する $\mathrm{Fc} レ$ セプター $(\mathrm{Fc} \gamma \mathrm{R})$ は, Fc $\gamma$ RI (CD64), Fc $\gamma$ RII (CDw32), Fc $\gamma$ RIII (CD16) の 3 種類が知られている. Fc $\gamma$ RI (CD64) は, monomeric IgG に対する高親和性レセプターであり, Fc $\gamma$ RII (CDw32) は, 凝集 IgG に対する低親和性レセ プターであって，FcrRIII（CD16）は，免疫複合体な どを結合する低親和性レセプターで ADCC の主要な 
レセプターである5).

最近, $\mathrm{T}$ 細胞レセプターを介した刺激と同等の刺激 と考光られている抗 CD3抗体刺激とヒト IgG1, ヒト $\mathrm{IgG} 3$, ヒト IgG4の刺激で, Fc $\gamma$ RI 依存性の細胞増殖が 確認されている6).

Akaza らの報告は, 末梢血単核球が腫瘍側腎を通過 する際に, 腫瘍局所に扔いて癌抗原刺激および免疫グ ロブリンによる刺激によって，これら Fc $\gamma \mathrm{R}$ 陽性細胞 が増加したと推測することができる。

以上より, 今回の検討は, 腎細胞癌患者の腫瘍局所 で生体の細胞性免疫反応が惹起されていることを示す 一つの所見であるとも考学られる。

しかし，CD25陽性細胞数の増加は，約 $13 \%$ と僅かな 増加であり，腎血流量が豊富であることを考兄合わせ ても, 短絡的に腫瘍局所での細胞性免疫反応が CD 25 陽性細胞数の増加の原因であると結論づけるのは早計 であろう。

症例を遠隔転移の有無で分けた場合，いずれも動脈 血々腫瘍側腎静脈血間のリンパ球サブセットに有意な 差は認めなかった。このことについては，測定した症 例数が少なく，さらに検討を続ける必要があると考兄 られた。

腎細胞癌患者のリンパ球サブセットの変化について は, 1984年にイギリスの Ritchie らが, 32例の腎癌患者 の末梢血リンパ球を分析し, 進行腎癌患者では, CD4陽 性細胞数の減少と, $\mathrm{CD} 4 / \mathrm{CD} 8$ 比の減少が生ずることを 報告している7). 今回の我々の結果も, 有意差は認めな かったものの，この報告と同様の傾向を示し，さらに CD8陽性かつ HLA-DR 陽性細胞の有意な増加を認め た. 今後, 症例を重ねさらに検討を加える必要がある と考えられる。

本文の要旨は, 1992 年 4 月, 第 80 回日本泌尿器科学会総会
（東京）にて白岩が発表した。

$$
\text { 文献 }
$$

1) Akaza, H., Kobayashi, K., Umeda, T. and Nijima, $T$.: Increase of $\mathrm{T}$ lymphocytes bearing immunoglobulin $\mathrm{G}$ receptors during circulation in human renal cell carcinoma. J. Urol., 128, 461-463, 1982.

2) 白岩浩志, 関根暉樹, 田中良典, 蔦巣賢一, 小磯謙 吉, 垣添忠生：固層化 CD3 抗体拉よびインターロ イキン 2 によるリンパ球活性化の基礎的検討. Biotherapy, 4, 427-433, 1990.

3) Gupta, S. and Good, R.A.: Subpopulations on human $\mathrm{T}$ lymphocytes. V. T lymphocytes with receptors for immunoglobulin $M$ or $G$ in patients with primary immunodeficiency disorders. Clin. Immunol. Immunopthol., 11, 292-302, 1978.

4）藤原光文：膀胀癌患者におけるIgG-Fcレセプ タ一陽性 $\mathrm{T}$ 細胞の動向. 日泌尿会誌, 80 , 1154-1161， 1989.

5）新保敏和, 石黒 精：CD 分類ハンドブック. CD 分類の項目別解説, 第 1 版, p. 12-96, 癌と化学療 法社, 東京, 1992.

6) Parren, P.W.H.I., Warmerdam, P.A.M., Boeije, L.C.M., Capel, P.J.A., van de Winkel, J.G.J. and Aarden, L.A.: Characterization of IgG FcRmediated prolifiration of human $T$ cells induced by mouse and human anti-CD3 monoclonal antibodies. Identification of a functional polymorphism to human IgG2 and anti-CD3. J. Immunol., 148, 695-701, 1992.

7) Ritchie, A.W.S., James, K., Micklem, H.S. and Chisholm, G.D.: Lymphocyte subsets in renal carcinoma-A sequential study using monoclonal antibodies. Br. J. Urol., 56, 140-148, 1984.

（1993年 2 月 9 日受理） 